\title{
小型チャンバーを用いた壁装材からの揮発性有機化合物の放散速度測定 MEASUREMENTS OF ALDEHYDES AND VOCS FROM WALL COVERING MATERIALS BY USING A SMALL CHAMBER
}

\author{
舟木理香*, 田辺新一** \\ Rika FUNAKI and Shin-ichi TANABE
}

\begin{abstract}
Emission rates of aldehydes and VOCs from wall coverings and powder type adhesives for wall coverings were investigated by using a small chamber. First, the measurements of emission rates were carried out for 16 types of wall covering materials. It was observed that the emission of formaldehyde from one of the samples was $17 \mu \mathrm{g} / \mathrm{m}^{2} \mathrm{~h}$ after one day, though that from almost all samples was less than $2 \mu \mathrm{g} / \mathrm{m}^{2} \mathrm{~h}$. The emission from wall coverings was much lower than the other building materials like floorings. Next, the measurements of emission rates were carried out for 3 types of powder type adhesives for wall covering materials. The emission for TVOC was very low with around $25 \mu \mathrm{g} / \mathrm{m}^{2} \mathrm{~h}$, but one of them for formaldehyde was high with $40 \mu \mathrm{g} / \mathrm{m}^{2} \mathrm{~h}$. It was found that all powder type adhesives were not low emission.
\end{abstract}

Keywords : Emission rates, VOCs, Aldehydes, Small chamber

放散速度, 揮発性有機化合物, アルデヒド類, 小型チャンバー

\section{1.はじめに}

近年，化学物質による室内空気污染が問題となっている。その対 策として，適切な換気を行うとともに，建材・施工材からの化学物 質放散特性を把握し, 低放散の建築材料を用いることが重要である。 建築材料から放散される化学物質の測定方法として，2003年 1 月に は JIS A1901「建築材料の揮発性有機化合物 (VOC), ホルムアルデ ヒド及び他のカルボニル化合物放散測定方法一小形チャンバー 法 $1^{1}$ が制定された。小型チャンバー法は，チャンバー内部に測定対 象とする建築材料の小片を設置し，内部を通常の室内のように換気 を行って放散を測定するものである2)。使用目的に応して様々な小 型チャンバーが提案されており，著者らは放散試験を目的とした小 型チャンパーADPAC (ADvanced Pollution and Air quality

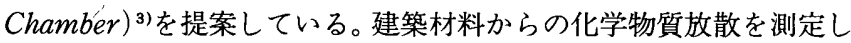
たデータとしては，床材，MDF，パーティクルボード，塗料などに ついて Brown ${ }^{4)}$, Chang ら ${ }^{5)}$, Negda ら ${ }^{6) の}$ 報告がある。また, Lundgren ら7), Van der Wal ら ${ }^{81}$ は PVC フローリングやカーペットなど について報告している。日本においては，神，村上ら ${ }^{9)}$ 市原ら ${ }^{10,11)}$, 池田ら ${ }^{12)}$ が小型チャンバーを用いて测定を行っているが，それぞれ， 塗料からの $\mathrm{VOC}^{9)}$, 床材, 接着剂などからのホルムアルデヒドと $\mathrm{TVOC}^{10,11)}$ ，壁紙からのホルムアルデヒドと $\mathrm{TVOC}^{12)}$ に関しての報 告で，特に居室内で大きな面積を占める壁装材からの VOC 等の放 散速度を広く体系的に測定し公表されているデー夕はほとんどな い。

$$
\text { そこで本研究では, シックハウス对策のために有意なデー夕を得 }
$$

ることを目的として,壁紙及び壁紙施工用接着剤に関して, 小型チャ ンバーを用いて化学物質放散速度測定を行ったのでその結果を報告 する。

\section{2. 小型チャンバーについて}

2-1 小型チャンバーの仕様

著者らが提案している小型チャンバー3)の基本的な性能は，欧州

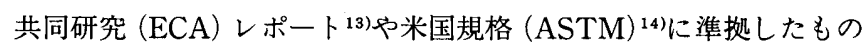
であり，新たに制定されたJIS A19011にも適合したチャンバーと なっている。小型チャンバーのシステムは，ステンレス製（SUS 304)のメインチャンバーと, チャンバーへの供給空気量及び湿度制

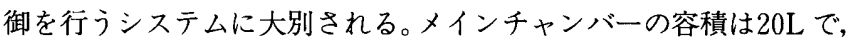
JIS A1901が示す容積範囲20１,000L の最小サイズである。チャン バーはバケット型の容器であり, 接合部は蓋部のみで, パッキング 部分にはテフロン製の枠を用いてシールしている。温度制御は恒温 槽内に設置して行う。チャンバー内部に試験体を設置する際は，化 学物質が試験体の表面のみから放散されるようにするために, 裏面 と試験体端部の小口面をシールするためのケース(シールボックス) を用いる。ケースはステンレス製（SUS 304）で，試験体とケース の間にテフロン枠を入れてシールし,後ろからネジで固定している。 放散面の大きさは，デンマーク建材ラベリング標準室の試験条件 ${ }^{15)}$ による試料負荷率 $2.2 \mathrm{~m}^{2} / \mathrm{m}^{3}$ に準じた場合, シールボックス 2 セット で必要面積となるサイズである。困 1 に小型チャンバーを用いた測 定風景とシールボックスを示す。
* 早稲田大学理工学総合研究センター 嘱託研究員・修士 (生活科学)

** 早稲田大学理工学部建築学科 教授・工博
Research Assoc., Advanced Research Institute for Science and Engineering, Waseda University, M. Lifescience

Prof., Department of Architecture, Waseda University, Dr. Eng. 

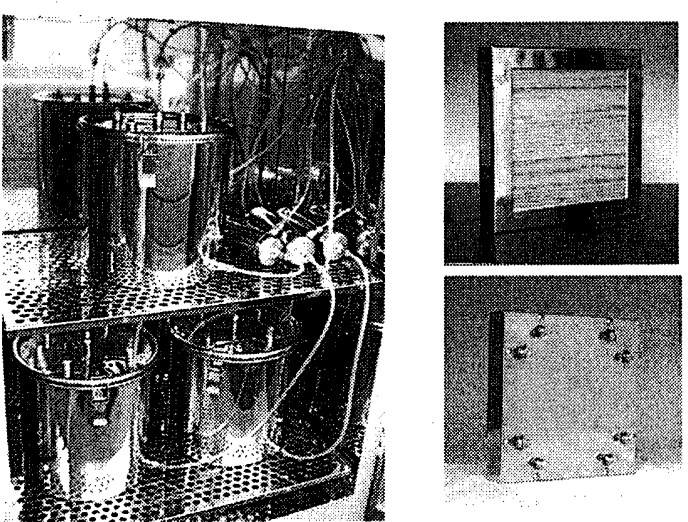

図 1 小型チャンバーを用いた测定風景とシールボックス

\section{2-2 測定手順・方法}

チャンバーは洗浄後加熱処理 $\left(260^{\circ} \mathrm{C}\right)$ L, 設置可能な温度まで泠 却した後，恒温槽内に設置する。30分程度システムを運転させ，温 湿度が定常に達した後で試験体をチャンバー内に入れる。化学物質 濃度が定常になるように約15時間換気を行った後，チャンバー内空 気を採取する。試験条件は，温度 $25 \pm 1{ }^{\circ} \mathrm{C}$ ，相对湿度 $50 \pm 4 \%$ ，換 気回数 0.5 回 $/ \mathrm{h}$, 試料負荷率 $2.2 \mathrm{~m}^{2} / \mathrm{m}^{3}$ とした。供給空気には, 小型 チャンバー試験用の空気清浄装置 ${ }^{16)}$ による清浄空気を用いた。アル デヒド類はDNPH 捕集管を用いて10L 捕集した。VOCはTenax TA 捕集管を用いて $3.2 \mathrm{~L}$ 捕集した。サンプリング後，アルデヒド類 は高速液体クロマトグラフィー (HPLC) で, VOC は加熱脱着しが スクロマトグラフ質量分析計 $(\mathrm{GC} / \mathrm{MS})$ で分析した。分析条件を表 1，2 に示す。本報における TVOC 值とは，n-hexane 以降のすべ てのピーク面積の総和をトルエン換算して求めたものである。

\section{3 . 壁紙からの放散速度測定}

\section{3-1 試験体について}

平成13年度の壁紙出荷量は,ビニル壁紙 $85.6 \%$, 無機質壁紙 $6.3 \%$,
表 1 アルデヒド類分析条件

\begin{tabular}{l|l}
\hline HPLC & Waters 2640 Separations Module alliance \\
\hline カラム & Nova-Pak ${ }^{\Phi} \mathrm{C}_{18, \phi}, 9.9 \times 150 \mathrm{~mm}$ \\
\hline 移動相 & 水:アセトニトリル:THF* $=65: 30: 5$ \\
\hline オーブン温度 & $40^{\circ} \mathrm{C}$ \\
\hline 注入量 & $20 \mu \mathrm{L}$ \\
\hline UV検出器 & Waters 2487 Dual $\lambda$ Absorbance Detector \\
\hline 検出波長 & $360 \mathrm{~nm}$ \\
\hline \multicolumn{2}{c}{} \\
\multicolumn{2}{c}{ *THF:tetrahy drofuran }
\end{tabular}

表 2 VOC 分析条件

\begin{tabular}{l|l}
\hline 加熱脱着装置 & Chrompack CP4020 \\
\hline トラップ温度 & $-130{ }^{\circ} \mathrm{C}$ \\
\hline 脱着流量 & $10 \mathrm{~mL} / \mathrm{min}$ \\
\hline 脱着温度 & $250^{\circ} \mathrm{C}$ \\
\hline GC/MS & Shimadzu QP -5000 \\
\hline カラム & HP-5MS $0.25 \mathrm{~mm} \varphi \times 60 \mathrm{~m} \times 0.25 \mathrm{~mm}$ \\
\hline オーブン温度 & $40^{\circ} \mathrm{C}(3 \mathrm{~min})-\left(10^{\circ} \mathrm{C} / \mathrm{min}\right)-300^{\circ} \mathrm{C}(10 \mathrm{~min})$ \\
\hline キャリアガス & $1 \mathrm{~mL} / \mathrm{min}($ ヘリウム $)$ \\
\hline モード & $\mathrm{SCAN}$ \\
\hline
\end{tabular}

紙壁紙3.1\%となっており,ビニル壁紙のマーケットシェアが非常に 大きい17)。本報では表 3 に示すビニル壁紙 11 種類, 紙壁紙 4 種類, オ レフィン系壁紙 1 種類の計 16 種類を対象として，化学物質放散速度 測定を行った。これらは一般的に市場流通している壁紙である。开 ンプルは，壁装材料協会規格「放散試験チャンバー法」18)に従い，工 場でロールの両端を除いた中央部分から幅なりで $1 \mathrm{~m}$ 採取し，通常 の生産方向にロール状に丸めてアルミ箔で包み，未印刷のポリエチ レン袋に入れて密閉されて実験室に送付されたものである。測定開 始日に開封し, 端から $20 \mathrm{~cm}$ 以上内側の部分から $14.7 \mathrm{~cm}$ 四方の正方 形に切り取ったものを試験体とした。試験体は両面発生とし，小口 部分のシールは行なわず，ステンレス製のつるしを用いて，チャン

表 3 壁紙の概要

\begin{tabular}{|c|c|c|c|c|c|c|c|c|}
\hline \multirow{2}{*}{ No. } & \multirow{2}{*}{ 種類 } & \multirow{2}{*}{$\begin{array}{c}\text { 重量 } \\
{\left[\mathrm{g} / \mathrm{m}^{2}\right]}\end{array}$} & \multicolumn{3}{|c|}{ 素材構成 } & \multicolumn{3}{|c|}{ 測定日 [day] } \\
\hline & & & 主素材 & 化粧層 & 毫打材 & 1 & 3 & 7 \\
\hline A & ビニル & 275 & 塩化ビニル樹脂、可塑剤、充填郕 & - & 紙 & 0 & 0 & \\
\hline B & ビニル & 245 & 塩化ビニル樹脂、可塑剤、充填剂 & 表面処理剤、インキ & 紙 & 0 & 0 & \\
\hline $\mathrm{C}$ & ビニル & 295 & 塩化ビニル樹脂、可塑剂、充填剂 & インキ & 紙 & 0 & 0 & \\
\hline D & ビニル & 251 & 塩化ビニル樹脂、可塑剤、充填咸 & 表面処理剂、インキ & 紙 & 0 & 0 & \\
\hline$E$ & ビニル & 250 & 塩化ビニル㴻脂、可塑剂、充填剂 & - & 紙 & 0 & 0 & \\
\hline $\mathbf{F}$ & ビニル & 216 & 塩化ビニル樹脂、可塑郕、充填㓮 & EVA*フィルム & 紙 & 0 & 0 & \\
\hline G & ビニル & 285 & 塩化ビニル檄脂、可塑郕、充填郕 & EVAフィルム & 紙 & 0 & $\mathrm{O}$ & \\
\hline $\mathrm{H}$ & ビニル & 268 & 塩化ビニル樹脂、可塑剂、充填剤 & - & 紙 & 0 & 0 & \\
\hline 1 & ビニル & 257 & 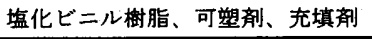 & - & 紙 & 0 & 0 & \\
\hline $\mathbf{J}$ & ビニル & 264 & 塩化ビニル樹脂、可塑刻、充填剤 & 表面処理剤、インキ & 紙 & 0 & $\mathrm{O}$ & \\
\hline $\mathrm{K}$ & ビニル & 238 & 塩化ビニル樹脂、可塑剤、充填郕 & - & 紙 & 0 & & 0 \\
\hline L & 紙 & 220 & 加工紙 & インキ、フィルム & - & 0 & 0 & \\
\hline$M$ & 紙 & 150 & 加工紙 & インキ、塗料 & - & $\mathrm{O}$ & 0 & \\
\hline $\mathrm{N}$ & 紙 & 220 & 加工紙 & EVAフィルム、フィルム用接着剂、インキ & 紙 & 0 & & 0 \\
\hline $\mathrm{O}$ & 紙 & 173 & 加工紙 & インキ、コーティング & - & 0 & & 0 \\
\hline $\mathbf{P}$ & オレフィン系 & 270 & 無機質充填鼡、着色剂 & EVAフィルム & 難燃紙 & 0 & & 0 \\
\hline
\end{tabular}


バ一内部に吊るして测定を行った。表 3 に示すように, $\mathrm{A} \sim \mathrm{J}$ 及び $\mathrm{L}$, $\mathrm{M}$ に関しては，測定期間中チャンバー内に設置したままの状態で 1 日目，3 日目に測定を行った。その他の $\mathrm{K} ， \mathrm{~N} ， \mathrm{O} ， \mathrm{P}$ は 1 日目， 7 日目に測定を行った。この 4 種の試験体に関しては，1 日目の測定 後にチャンバーから取り出して実験室内に保管, 測定前日にチャン バー内に戻して，チャンバー内濃度が定常になるまで換気した後に 7 日目の測定を行った。

\section{3-2 測定結果}

今回，厚生労働省がガイドライン值 ${ }^{19)}$ をしている物質に注目し た。スチレン，エチルベンゼン，キシレン等に関しては，放散がほ とんど見られなかった。ホルムアルデヒド，アセトアルデヒド，ト ルエンについて，1 日目で $1 \mu \mathrm{g} / \mathrm{m}^{2} \mathrm{~h}$ 以上の放散を示したサンプル に関して図 $2 \sim 4$ に測定結果を示す。

図 2 にホルムアルデヒドの放散速度測定結果を示す。1 日目に $1 \mu \mathrm{g} / \mathrm{m}^{2} \mathrm{~h}$ 以上の放散がみられた壁紙は，16サンプル中 7 サンプルあ ク, B では $17 \mu \mathrm{g} / \mathrm{m}^{2} \mathrm{~h}, \mathrm{~N}$ で $12 \mu \mathrm{g} / \mathrm{m}^{2} \mathrm{~h}, \mathrm{O}$ で $8 \mu \mathrm{g} / \mathrm{m}^{2} \mathrm{~h}, \mathrm{M}$ 及び $\mathrm{K} て ゙$ $4 \mu \mathrm{g} / \mathrm{m}^{2} \mathrm{~h}$ の放散が見られた。Bは 3 日目には検出限界，Nは 7 日目 に $7 \mu \mathrm{g} / \mathrm{m}^{2} \mathrm{~h}, \mathrm{O}$ は $1 \mu \mathrm{g} / \mathrm{m}^{2} \mathrm{~h}$ となり, 平均低減率は 3 日目で $56 \%, 7$

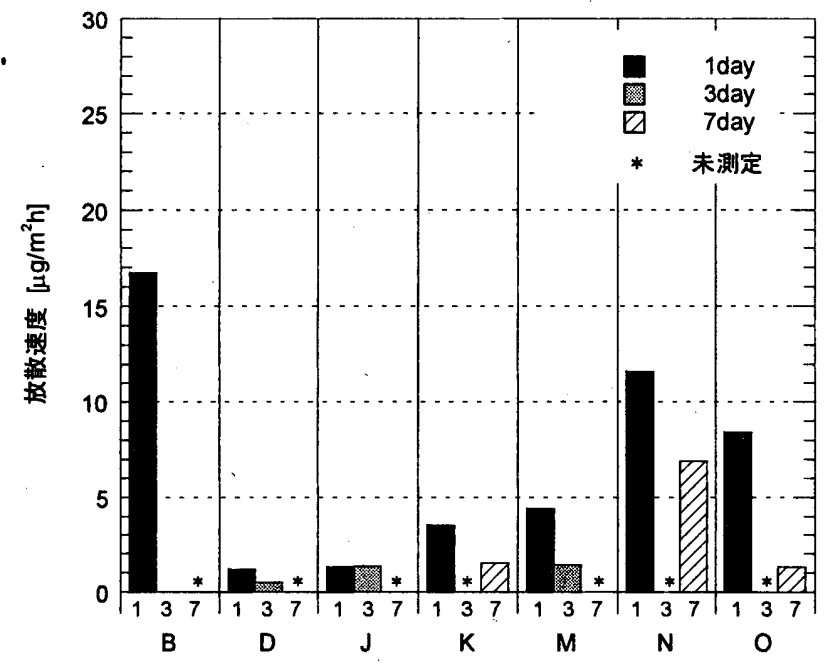

図 2 壁紙一ホルムアルデヒド放散速度

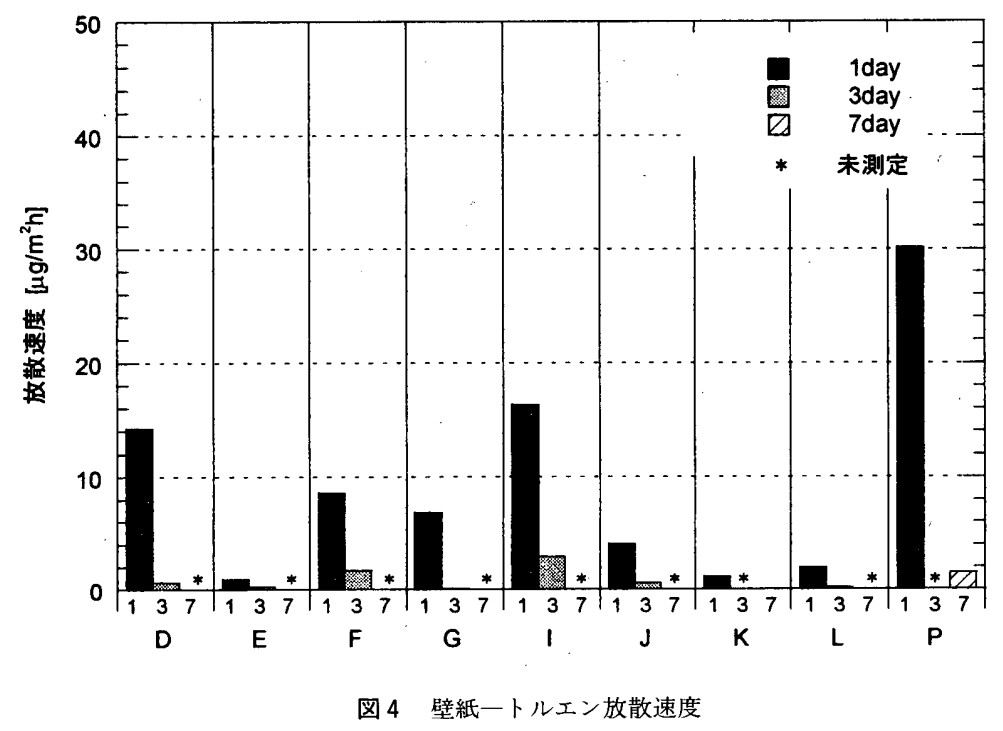

日目では1日目の $61 \%$ とっていた。

困 3 にアセトアルデヒドの放散速度測定結果を示す。1 日目に $1 \mu \mathrm{g} / \mathrm{m}^{2} \mathrm{~h}$ 以上の放散がみられた壁紙は 16 サンプル中 3 サンプルで, $2 \mu \mathrm{g} / \mathrm{m}^{2} \mathrm{~h}$ を超えたものはなかった。

図 4 にトルエンの放散速度測定結果を示す。1 日目に $1 \mu \mathrm{g} / \mathrm{m}^{2} \mathrm{~h}$ 以上の放散がみられた壁紙は, 16 サンプル中 9 サンプルあり，Pのオ レフィン系壁紙で $30 \mu \mathrm{g} / \mathrm{m}^{2} \mathrm{~h}$ と最も高く, その他ビニル壁紙の I, D, $\mathrm{F}, \mathrm{G}$ の順番で放散が高く，I では $16 \mu \mathrm{g} / \mathrm{m}^{2} \mathrm{~h}, \mathrm{D}$ で $14 \mu \mathrm{g} / \mathrm{m}^{2} \mathrm{~h}, \mathrm{~F}$ で $9 \mu \mathrm{g} / \mathrm{m}^{2} \mathrm{~h}, \mathrm{G}$ で $7 \mu \mathrm{g} / \mathrm{m}^{2} \mathrm{~h}, \mathrm{~J} て ゙ ~ 4 \mu \mathrm{g} / \mathrm{m}^{2} \mathrm{~h}$ であった。トルエンの放散 速度に関する 3 日目の平均低減率は $88 \%$ であった。

表 4 に 1 日目の主な放散成分を，図 5 に TVOCの放散速度測定 結果を示す。ビニル壁紙で放散が大きく，I で $1510 \mu \mathrm{g} / \mathrm{m}^{2} \mathrm{~h} ， \mathrm{C}$ で540 $\mu \mathrm{g} / \mathrm{m}^{2} \mathrm{~h}, \mathrm{D}$ で $448 \mu \mathrm{g} / \mathrm{m}^{2} \mathrm{~h}, \mathrm{~F}$ で $416 \mu \mathrm{g} / \mathrm{m}^{2} \mathrm{~h}, \mathrm{~B}$ で $380 \mu \mathrm{g} / \mathrm{m}^{2} \mathrm{~h}, \mathrm{E}$ で $289 \mu \mathrm{g} / \mathrm{m}^{2} \mathrm{~h}, \mathrm{~A}$ 及び $\mathrm{K} て ゙ 246 \mu \mathrm{g} / \mathrm{m}^{2} \mathrm{~h}$ となった。これらの主な放散成 分は, 表 4 に示寸ようにウンデカン，ドデカン，テトラデカンなど の炭化水素類が多く見られた。ビニル壁紙に関して 3 日目には放散 速度が平均で78\%減少している一方, 紙壁紙 L, M, N, O は 1 日目 の放散速度が $150 \mu \mathrm{g} / \mathrm{m}^{2} \mathrm{~h}$ 以下でビニル壁紙と比べると初期放散が

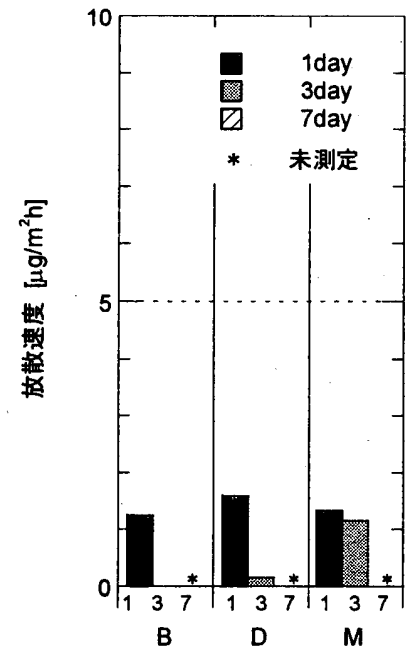

図３＼cjkstart壁紙一アセトアルデヒド放散速度 低く，経時による平均低減率 は $16 \%$ と急激な変化は見られ なかった。放散主成分として は炭化水素類の他, アルコー ル類の放散が多かった。ま

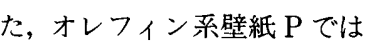
1 日目で290 $\mu \mathrm{g} / \mathrm{m}^{2} \mathrm{~h}$ の放散 速度を示しており，エチレン グリコールが $24 \%$ 占めて いた。7日目には半減し 150 $\mu \mathrm{g} / \mathrm{m}^{2} \mathrm{~h}$ であった。

池田ら ${ }^{12)}$ は同様に20Lの小 型チャンバーを用いてビニル 2 種, 紙, オレフィン系, 不 織布の計 5 種類の壁紙につい て測定を行っており，ホルム アルデヒドに関しては紙壁紙 で約 $13 \mu \mathrm{g} / \mathrm{m}^{2} \mathrm{~h}$ ，その他は $2 \mu \mathrm{g} / \mathrm{m}^{2} \mathrm{~h}$ 以下という結果を報 告している。また，TVOCに関しては，ビニル壁紙で900 $\mu \mathrm{g} / \mathrm{m}^{2} \mathrm{~h}$ ，オレフィン系壁紙で $400 \mu \mathrm{g} / \mathrm{m}^{2} \mathrm{~h}$ という結果を得 ている。今回著者らが測定した値と比較すると，ホルムア ルデヒドに関しては, 紙壁紙 $\mathrm{N} て ゙ 12 \mu \mathrm{g} / \mathrm{m}^{2} \mathrm{~h}$, オレフィン系 壁紙 P では $1 \mu \mathrm{g} / \mathrm{m}^{2} \mathrm{~h}$ 以下とほぼ同様の結果となってい る。ビニル壁紙に関しても, B $17 \mu \mathrm{g} / \mathrm{m}^{2} \mathrm{~h}$ 以外は同様の結 果を示した。TVOCに関しても同程度の結果が得られた。

今回の測定結果から，壁紙単体としての化学物質の放散 は，フローリング材 ${ }^{20)}$ 上りも低いものが多いことがわかっ た。また， 3 日目には放散が半減しているサンプルが大半 であったことから，初期放散の影響が大きいことに注意す る必要があることがわかった。壁面は室内の占有面積が大 きいため, 壁紙の色柄や風合いは室内のデザイン性を大き く左右する。安全性のみならず, 耐水性や耐光性, 施工性, 
表 4 壁紙からの 1 日目の主な放散成分（ホルムアルデヒド，アセトアルデヒド，トルエン以外)

\begin{tabular}{|c|c|c|c|c|c|c|c|c|}
\hline 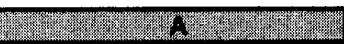 & (ntry & manth & YXe & W & Thimen & 4: & RT & 7men'm \\
\hline tetradecane $^{b)}$ & $18.2 \sim 24$ & 120.9 & undecane $^{\mathrm{b})}$ & \multirow{2}{*}{$12 \sim 21$} & \multirow{2}{*}{127.8} & 6-methylheptyl acrylate & 18.48 & 34.7 \\
\hline decane $e^{c)}$ & $12.8 \sim 17$ & 101.0 & decane & & & 2-(2-butoxyethoxy)ethanol & 17.87 & 17.2 \\
\hline ethylhexanoic acid & 17.29 & 25.1 & 2-(2-methoxyethoxy)ethanol & 13.24 & 15.3 & acetic acid & 7.55 & 8.6 \\
\hline 2-(2-butoxyethoxy)ethanol & 17.90 & 4.6 & 2-(2-butoxyethoxy)ethanol & 17.77 & 9.8 & ethylhexanol & 14.92 & 2.6 \\
\hline 2-butoxyethanol & 12.41 & 2.2 & 2-ethylhexanol & 14.86 & 5.4 & n-octylacetate & 17.07 & 2.3 \\
\hline formamide & 8.90 & 1.7 & 2-butoxyethanol & 12.49 & 5.3 & 2-isopropoxyethanol & 11.52 & 2.1 \\
\hline acetic acid & 7.33 & 0.7 & 2,5-bis(1,1-dimethylpropyl) & \multirow{2}{*}{24.88} & \multirow{2}{*}{4.7} & hexadecane & 23.78 & 2.0 \\
\hline 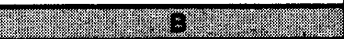 & (2) 201 & Thind & -2,5-cyclohexadiene-1,4-dione & & & pentadecane & 22.45 & 1.9 \\
\hline undecane $e^{d)}$ & $12.5 \sim 22.2$ & 350.3 & formamide & 8.99 & 4.1 & 2-ethylhexanol & 18.58 & 1.7 \\
\hline propanoic acid & 9.25 & 27.7 & acetic acid & 7.25 & 1.8 & tetradecane & 21.03 & 1.2 \\
\hline $\mathrm{N}, \mathrm{N}$-dimethylformamide & 10.26 & 4.4 & $\mathrm{~N}, \mathrm{~N}$-dimethylformamide & 10.18 & 1.5 & DIV & \multicolumn{2}{|c|}{ RT [netwen } \\
\hline 2-butoxyethanol & 12.44 & 2.8 & propylene glycol & 9.35 & 1.4 & 2-butoxyethanol & 12.44 & 6.7 \\
\hline 37.0. & WT & 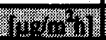 & (1978) & PeT & $m m^{3}$ & 2-ethylhexanol & 14.81 & 1.7 \\
\hline undecane $e^{c}$ & $12.5 \sim 21.08$ & 500.0 & undecane $\mathrm{i}^{\mathrm{i})}$ & $13 \sim 24$ & 54.1 & 2,5-bis(1,1-dimethylpropyl) & \multirow{2}{*}{24.05} & \multirow{2}{*}{1.7} \\
\hline formamide & 9.91 & 17.5 & 2-(2-butoxyethoxy)ethanol & 16.16 & 6.8 & -2,5-cyclohexadiene-1,4-dione & & \\
\hline 3-methoxy-1-butanol & 11.00 & 4.5 & 2-butoxyethanol & 12.49 & 2.1 & phenol & 13.87 & 1.7 \\
\hline acetic acid & 7.18 & 4.4 & acetic acid & 7.55 & 1.6 & acetic acid & 6.95 & 1.5 \\
\hline 2-butoxyethanol & 12.42 & 2.3 & 3-methoxybutanol & 11.19 & 0.8 & 1-butanol & 7.28 & 1.4 \\
\hline 2,5-bis(1,1-dimethylpropyl) & \multirow{2}{*}{24.98} & \multirow{2}{*}{1.9} & Fif & RUI & (7) & benzothiazol & 18.70 & 1.3 \\
\hline -2,5-cyclohexadiene-1,4-dione & & & dodecane $e^{j}$ & $11 \sim 24$ & 1473.1 & hexanal & 10.04 & 1.1 \\
\hline 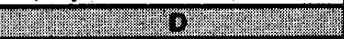 & $1.1 \mathrm{mP}$ & Ting & formamide & 9.00 & 7.1 & 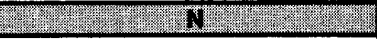 & RT & (Hom \\
\hline decane $^{f}$ & \multirow{3}{*}{$11.7 \sim 16.1$} & \multirow{3}{*}{186.6} & acetic acid & 7.40 & 2.8 & 2-(2-butoxyethoxy)-ethanol & 26.51 & 83.7 \\
\hline undecane & & & 1-butanol & 7.31 & 2.1 & 2-butoxyethanol & 20.60 & 1.7 \\
\hline nonane & & & heptane & 7.95 & 1.2 & 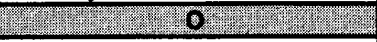 & RT & (15:2muln \\
\hline 3,5,5-trimethylcyclohexenone & 16.94 & 77.6 & (3) & RT: & Th:min & 2-ethyl-1-hexanol & 23.42 & 3.2 \\
\hline formamide & 9.14 & 8.5 & cyclohexanone & 12.56 & 113.2 & 4-methyl-2-undecene & 23.52 & 2.4 \\
\hline 2-(2-butoxyethoxy)ethanol & 17.81 & 7.6 & dodecane & 17.97 & 39.5 & 1-ethyl-2,4-dimethyl benzene & 26.77 & 2.2 \\
\hline ethylacetate & 6.54 & 6.9 & 2-(2-butoxyethoxy)ethanol & 17.83 & 3.8 & 2-ethyl-1,4-dimethyl benzene & 24.46 & 2.2 \\
\hline 2-butanone & 6.31 & 6.0 & acetic acid & 7.55 & 2.4 & acetic acid & 10.37 & 1.8 \\
\hline acetic acid & 7.65 & 3.9 & formamide & 9.00 & 2.4 & 1,2,4-trimethyl benzene & 23.97 & 1.8 \\
\hline xylene & & 3.7 & n-decylmethacrylate & 16.76 & 1.7 & 4-ethyl-1,2-dimethyl benzene & 25.00 & 1.8 \\
\hline 2-butoxyethanol & 12.47 & 3.1 & benzaldehyde & 13.77 & 1.3 & 1,4-dichloro benzene & 23.72 & 1.7 \\
\hline ethylbenzene & & 2.8 & tridecane & 19.50 & 1.0 & 2-butoxyethanol & 20.59 & 1.7 \\
\hline 2,5-bis(1,1-dimethylpropyl) & \multirow{2}{*}{24.87} & \multirow{2}{*}{2.6} & $3+2 . \mathrm{B}$ & RT & Tromintin & 1,3,5-trimethyl benzene & 23.24 & 1.6 \\
\hline -2,5-cyclohexadiene-1,4-dione & & & 1,2,3-trimethyl benzene & 23.23 & 16.5 & 1,2,4,5-tetramethyl benzene & 25.97 & 1.2 \\
\hline Weste & 29: 21 & Trgingul & 2,6-dimethyl octadecane & 23.64 & 12.1 & phenol & 21.96 & 0.8 \\
\hline dodecane & 17.94 & 91.2 & undecane & 25.14 & 12.0 & 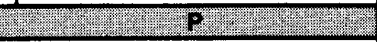 & $\frac{k T}{130}$ & mothen \\
\hline ethylhexanoic acid & 17.21 & 80.7 & decane & 23.07 & 8.9 & 1,2-ethanediol & 13.95 & 69.2 \\
\hline undecane & 16.17 & 38.3 & 1,3,5-trimethyl benzene & 23.24 & 7.8 & pentane & 8.54 & 52.2 \\
\hline tridecane & 19.47 & 14.4 & 1,2,4-trimethyl benzene & 23.96 & 7.2 & cyclohexanone & 20.53 & 31.7 \\
\hline tetradecane & 20.97 & 7.2 & 1-methyl-2-(1-methylethyl)benzene & 24.98 & 7.0 & hexane & 12.00 & 22.5 \\
\hline 2-ethylhexanol & 14.85 & 4.7 & 1-methyl-4-(1-methylethyl)benzene & 24.45 & 6.4 & propylene glycol & 15.39 & 5.0 \\
\hline 2-butoxyethanol & 12.64 & 4.0 & 1-ethyl-2,3-dimethyl benzene & 25.68 & 6.3 & 2-butanone & 11.12 & 4.2 \\
\hline formamide & 7.13 & 1.7 & 4-methyl decane & 24.39 & 5.9 & methyl isobutyl ketone & 16.03 & 2.6 \\
\hline phenol & 13.94 & 1.6 & 4-ethyl-1,2-dimethyl octadecane & 23.72 & 5.8 & acetic acid & 10.45 & 2.1 \\
\hline fente- & DII & 1. & 3-methyl decane & 24.62 & 5.7 & methyl cyclopentane & 13.16 & $1: 8$ \\
\hline undecane ${ }^{\mathrm{g})}$ & \multirow{4}{*}{$12.4 \sim 20.1$} & \multirow{4}{*}{416.5} & 2,3-dimethyl octane & 21.98 & 5.6 & 3-methyl pentene & 11.48 & 1.6 \\
\hline nonane & & & 1-methyl-2-propyl benzene & 24.85 & 4.2 & & & \\
\hline decane & & & 1-ethyl-2-methyl benzene & 22.41 & 4.1 & & & \\
\hline dodecane & & & methyl isobutyl ketone & 16.03 & 2.6 & & & \\
\hline formamide & 9.00 & 2.0 & dodecane & 27.04 & 2.3 & & & \\
\hline acetic acid & 7.22 & 1.4 & 2-butanone & 11.11 & 1.8 & & & \\
\hline & & & acetic acid & 10.35 & 1.4 & & & \\
\hline
\end{tabular}

a) Retention Time(保持時間)。分析時に試料注入後、クロマトグラムでピークの頂点が現れるまでの時間[分]。

b) A の tetradecane は 18.2 24 分の炭化水素分布の代表例。值は18.2〜24 分のオイル分布の合計である。

c) Aの decane は $12.8 \sim 17.0$ 分の炭化水素 (アルカン+アルケン) 分布の代表例。值は $12.8 \sim 17.0$ 分のオイル分布の合計である。

d) B の undecane は $12.5 \sim 22.2$ 分の炭化水素 (アルカン+アルケン) 分布の代表例。值は12.5〜 22.2 分のオイル分布の合計である。

e) Cの undecane は $12.5 \sim 21.08$ 分の炭化水素 (アルカン+アルケン) 分布の代表例。值は $12.5 \sim 21.08$ 分のオイル分布の合計である。

f) Dの nonane、decane、 undecane は $11.7 \sim 16.1$ 分の炭化水素（アルカン+アルケン+芳香族）分布の代表例。值は11.7〜16.1 分のオイル分布の合計である。 但し、2-butoxyethanol を除く。

g) F の nonane 〜 dodecane は $12.4 \sim 20.1$ 分の炭化水素（アルカン+アルケン)分布の代表例。值は12.5〜20 分のオイル分布の合計である。

h) Gの decane、undecane は $12 \sim 21$ 分の炭化水素（アルカン+アルケン+芳香族）分布の代表例。值は12〜21 分のオイル分布の合計である。

但 $L 、 2-(2-$-methoxyethoxy)ethanol、2-(2-butoxyethoxy)ethanol、2-ethylhexanol、2-butoxyethanol

i) $\mathrm{H}$ の undecane は $13 \sim 24$ 分の炭化水素（アルカン+アルケン）分布の代表例。值は13〜24 分のオイル分布の合計である。

但し、2-(2-butoxyethoxy)ethanol、2-butoxyethanol を除く。

j) Jの dodecane は $11 \sim 24$ 分の炭化水素（アルカン+アルケン）分布の代表例。值は11〜24 分のオイル分布の合計である。 


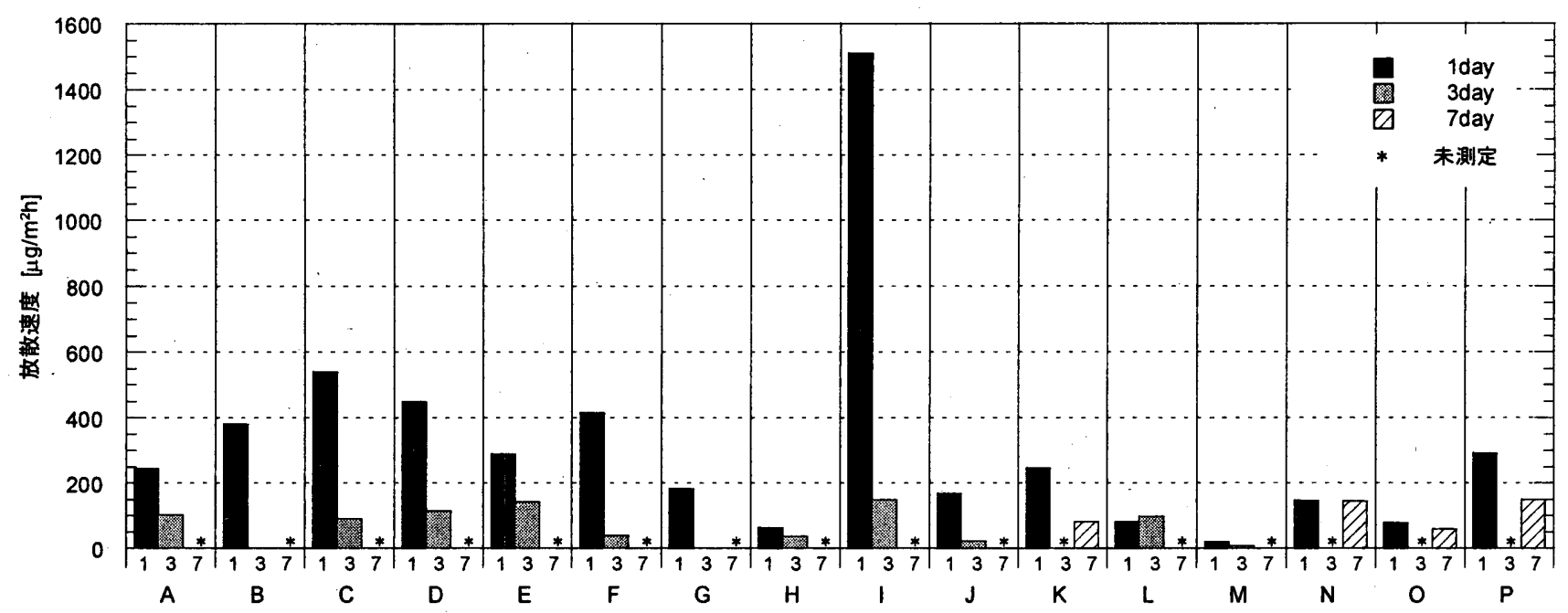

図 5 壁紙一TVOC 放散速度

防火性，デザイン性を考慮して選定する必要がある。

\section{4 . 壁紙施工用粉末接着剤からの放散速度測定}

\section{4-1 試験体について}

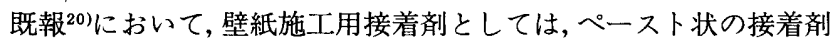
と比べて粉末状の接着郕でVOC,アルデヒド類ともに放散が低かっ た。そこで, 本報では新たに表 5 に示す $\mathrm{W}, \mathrm{U}, \mathrm{S}$ の 3 種類の壁紙施 工用粉末接着剂について試験を行い, 測定データを得ることとした。 これらは一般に市場流通している接着剂である。表 5 中には比較と して $\mathrm{K} ， \mathrm{E} ， \mathrm{R}$ も示す。 $\mathrm{K} ， \mathrm{E} ， \mathrm{R}$ は既報20)により測定結果を得てい る接着剤で, $\mathrm{K}$ 及び $\mathrm{E} は 今$ 今回測定した接着剤と同様の粉末接着剂, $\mathrm{R}$ はぺースト状の接着剤でも低い值を示した接着剤である。12mm 厚の石育ボードを下地として，それぞれ刷毛で均一に塗布したもの を試験体とした。下地への接着剂叙布量は $160 \mathrm{~g} / \mathrm{m}^{2}$ とし, 試料負荷率 $2.2 \mathrm{~m}^{2} / \mathrm{m}^{3}$ の条件から, $165 \mathrm{~mm}$ 四方の試験体 1 枚につき $4.3 \mathrm{~g}$ 塗布し た。チャンバー内部にはシールボックスを使用して設置したため, 測定にはそれぞれ 2 枚用いた。施工後 3 時間乾燥させたものを小型 チャンバー内部に設置して 7 日目までの経時変化を測定した。試験 条件，サンプリング条件，分析条件は2-2項と同様である。

\section{4-2 測定結果}

図 6 に 1 日目のアルデヒド類放散速度測定結果を示す。ホルムア ・ルデヒドに関しては，W，Uの放散速度はいずれも $5 \mu \mathrm{g} / \mathrm{m}^{2} \mathrm{~h}$ 以下と 低かったが, Sについては $40 \mu \mathrm{g} / \mathrm{m}^{2} \mathrm{~h}$ と高い值を示しており, 粉末接

表 5 壁紙施工用接着剂の概要

\begin{tabular}{|c|c|c|}
\hline & 主成分 & $\begin{array}{c}\text { 調整条件 } \\
\text { (接着鼡／水) }\end{array}$ \\
\hline W & ポリビニルアルコール & $240 \mathrm{~g} / 4.0 \mathrm{~L}$ \\
\hline $\mathrm{U}$ & セルロース、ポリビニルアルコール & $114 \mathrm{~g} / 5.0 \mathrm{~L}$ \\
\hline $\mathrm{S}$ & 非公開 & $200 \mathrm{~g} / 5.5 \mathrm{~L}$ \\
\hline K & $\begin{array}{l}\text { エーテル化架橋· } \alpha \text { 澱粉: } 90 \% \\
\text { 酢酸ビニル椥脂: } 10 \%\end{array}$ & $338 \mathrm{~g} / 2.3 \mathrm{~L}$ \\
\hline E & $\begin{array}{l}\text { Natural starch powder: } 99.7 \% \\
\text { Carbendazim } * 0.3 \%\end{array}$ & $100 \mathrm{~g} / 120 \mathrm{~g}$ \\
\hline $\mathbf{R}$ & 酢酸ビニル、澱粉 & $180 \mathrm{~g} / 108 \mathrm{~g}$ \\
\hline
\end{tabular}

着剂でもホルムアルデヒドの放散が高いものがあることがわかっ た。 $\mathrm{K} ， \mathrm{E} ， \mathrm{R}$ と比較しても高い值を示しており，Sに関しては対策 が必要であると考えられる。アセトアルデヒドに関しては，すべて の接着剂で $2 \mu \mathrm{g} / \mathrm{m}^{2} \mathrm{~h}$ 程度と低い值を示していた。

図 7 に 1 日目の VOC 放散速度測定結果を示す。W，U, S ともに 放散は TVOC 值で $25 \mu \mathrm{g} / \mathrm{m}^{2} \mathrm{~h}$ 程度であり，同じ粉末状の $\mathrm{K} て ゙ 246$ $\mu \mathrm{g} / \mathrm{m}^{2} \mathrm{~h}, \mathrm{E}$ で $838 \mu \mathrm{g} / \mathrm{m}^{2} \mathrm{~h}$, ペースト状の $\mathrm{R} て ゙ 170 \mu \mathrm{g} / \mathrm{m}^{2} \mathrm{~h}$ を示して いたのと比較すると VOC の放散速度はいずれもかなり低い值で あった。表 $6 に \mathrm{~W}, \mathrm{U}, \mathrm{S}$ の主な放散成分を示す。上位成分としては それぞれ共通して，スチレン，トルエン，ジクロロメタン，眽酸ブ チルが見られた。

図 8，9に W, U, S に関して 7 日目までのホルムアルデヒド及び TVOCの経時変化を示す。ホルムアルデヒドに関して，W，Uは初 期段階から $2 \sim 4 \mu \mathrm{g} / \mathrm{m}^{2} \mathrm{~h}$ と低い放散でほとんど変化は見られな かった。一方, 放散の高かった Sに関しては 7 日目で $18 \mu \mathrm{g} / \mathrm{m}^{2} \mathrm{~h}$ と 1 日目より $55 \%$ 減少し，半分以下の放散となっていたが，W，Uと比 較すると約 4 倍の値を示した。TVOCに関しては，W，U，S それ ぞれ同様の傾向を示しており，1 日後に $24 \sim 28 \mu \mathrm{g} / \mathrm{m}^{2} \mathrm{~h}$ であった放 散が 7 日後には $13 \sim 17 \mu \mathrm{g} / \mathrm{m}^{2} \mathrm{~h}$ と約 $40 \%$ 減衰していた。

接着剤からの放散が初期に高い值であっても 1 週間でほぼ半減す ることがわかったことから, 健康性を確保するためには, 化学物質 の放散が高いと考えられるものでも，施工後一定の放散期間を設け ることで健康被害を軽減することができると予想される。今回测定 した粉末接着剂は最初に水に溶かすなど手間がかかる一方，オープ ンタイムが長く，作業性に優れ，経済的であるなどの特徴がある21） 接着剂にはそれぞれ使用用途・特徴があり，成分を抑制すると接着 強度に問題が生じる可能性がある。従って, 個々の接着剂の特徵を 活かした安全性の高い製品の開発が望まれる。

\section{5.まとめ}

壁紙及び壁紙施工用粉末接着剂からの化学物質放散速度に関し て, 容積 $20 \mathrm{~L}$ の小型チャンバーを用いて測定を行ったところ, 以下の 結果が得られた。

1 ）16種類の壁紙について測定を行った。壁紙単体からの化学物質 


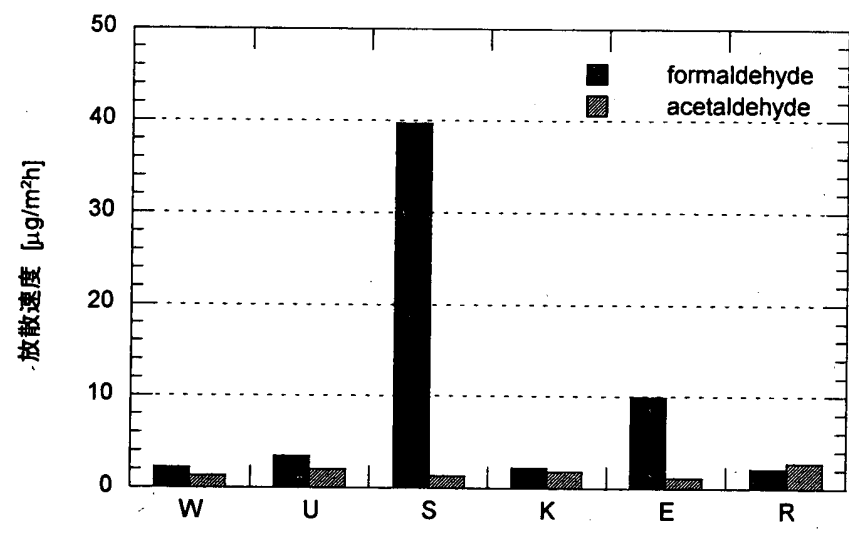

図 6 壁紙用粉末接着剤一 1 日目アルデヒド類放散速度

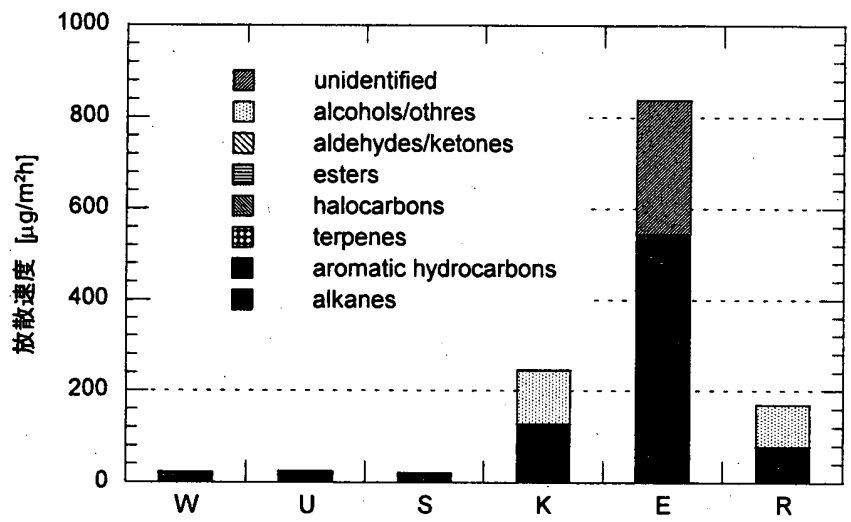

図 7 壁紙用粉末接着剂一 1 日目 VOC 放散速度

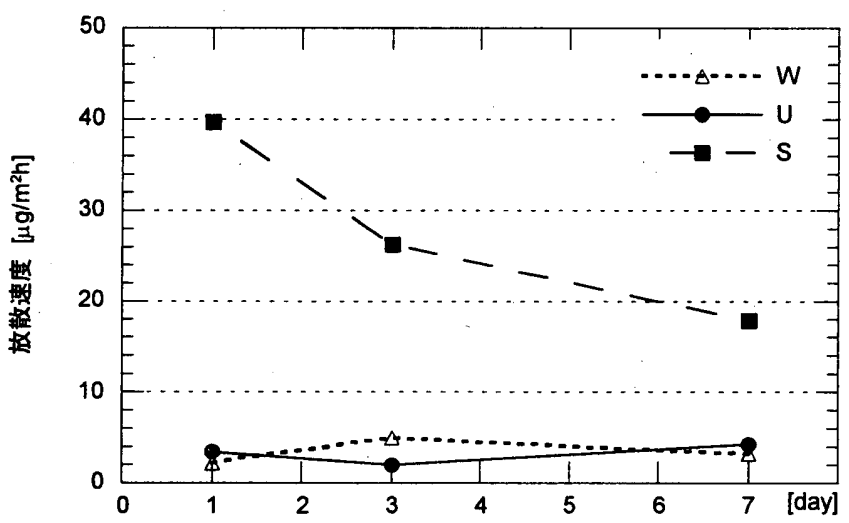

図 8 壁紙用粉末接着剂一ホルムアルデヒド放散速度経時変化

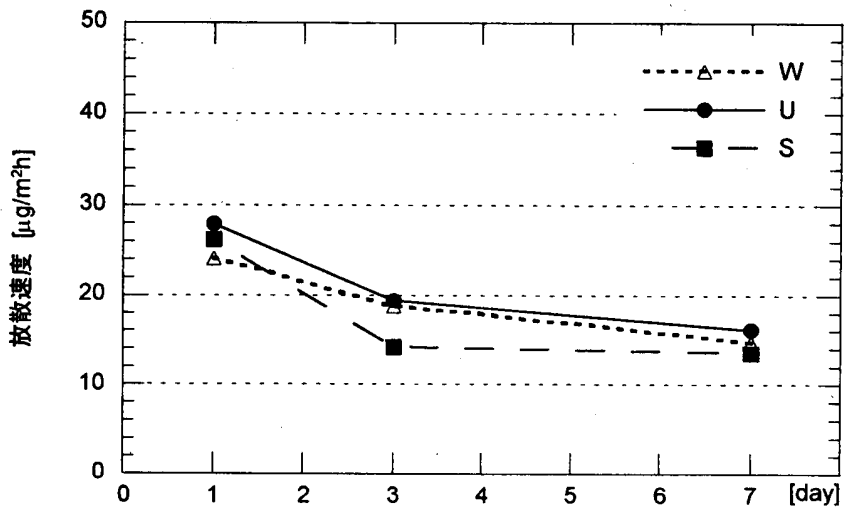

図 9 壁紙用粉末接着剂一TVOC 放散速度経時変化
表 6 壁紙用粉末接着剂 $(\mathrm{W}, \mathrm{U}, \mathrm{S})$ からの主な放散成分 $\left[\mu \mathrm{g} / \mathrm{m}^{2} \mathrm{~h}\right]$

\begin{tabular}{c|l|c|c|c}
\hline & \multicolumn{1}{|c|}{ 成分 } & lday & 3day & 7 day \\
\hline \multirow{4}{*}{$\mathrm{W}$} & sty rene & 5 & 3 & 2 \\
\cline { 2 - 5 } & butylacetate & 4 & 2 & 1 \\
\cline { 2 - 5 } & toluene & 3 & 2 & 1 \\
\cline { 2 - 5 } & dichloromethane & 3 & 2 & 3 \\
\cline { 2 - 5 } & nonanal & 1 & 1 & 1 \\
\hline \multirow{4}{*}{$\mathrm{U}$} & sty rene & 6 & 4 & 2 \\
\cline { 2 - 5 } & toluene & 6 & 3 & 1 \\
\cline { 2 - 5 } & dichloromethane & 3 & 3 & 4 \\
\cline { 2 - 5 } & butylacetate & 2 & 1 & 1 \\
\cline { 2 - 5 } & nonanal & 1 & 1 & 1 \\
\hline \multirow{4}{*}{$\mathrm{S}$} & sty rene & 4 & 1 & 1 \\
\cline { 2 - 5 } & dichloromethane & 3 & 3 & 4 \\
\cline { 2 - 5 } & butylacetate & 3 & 2 & 1 \\
\cline { 2 - 5 } & toluene & 2 & 1 & $<1$ \\
\cline { 2 - 5 } & tetradecane & 1 & 1 & 2 \\
\cline { 2 - 5 } & nonanal & 1 & 1 & 1 \\
\hline
\end{tabular}

の放散は, フローリング材からの放散に比較すると全般的に低い 放散であった。

2) 厚生労働省がガイドライン值を示している物質に関して特に注 目したところ，16サンプルのうち，1 日目に $1 \mu \mathrm{g} / \mathrm{m}^{2} \mathrm{~h}$ 以上の放散 がみられた壁紙は, ホルムアルデヒドに関しては 7 サンプル，ア セトアルデヒドでは 3 サンプル，トルエンでは 9 サンプルであっ た。1日目のホルムアルデヒドの最高値は B の $17 \mu \mathrm{g} / \mathrm{m}^{2} \mathrm{~h}$, トルエ ンでは P の $30 \mu \mathrm{g} / \mathrm{m}^{2} \mathrm{~h}$, TVOC では I の $1510 \mu \mathrm{g} / \mathrm{m}^{2} \mathrm{~h}$ であった。ア セトアルデヒドに関してはすべてにおいて $2 \mu \mathrm{g} / \mathrm{m}^{2} \mathrm{~h}$ 以下と低い 值であった。スチレンキシレンはほとんど放散が見られなかっ た。

3 ）ビニル壁紙ではテトラデカンを含むアルカン類が多く放散され ていた。

4） 1 日目の TVOCに関して平均すると，ビニル壁紙は $408 \pm 391$ $\mu \mathrm{g} / \mathrm{m}^{2} \mathrm{~h}$, 紙壁紙は $81 \pm 53 \mu \mathrm{g} / \mathrm{m}^{2} \mathrm{~h}$ となり, 平均值で比較すると紙 壁紙はビニル壁紙の 5 分の 1 程度の低い值を示した。

5 ）壁紙からの放散は，1 日目と 3 日目を比較するとホルムアルデ ヒドでは平均 $56 \%$ ，アセトアルデヒドでは平均 $77 \%$ ，トルエンで は平均 $88 \%$, TVOC では平均 $68 \%$ の減衰が見られ，放散は急激に 低減することがわかうた。包装開封直後の放散に注意する必要が ある。

6 ）壁紙施工用粉末接着剂からの放散は，既報の接着剂20)と比較 しても低い值であったが，ホルムアルデヒドに関しては，Sで40 $\mu \mathrm{g} / \mathrm{m}^{2} \mathrm{~h}$ といj結果が見られ, 粉末接着剂でもホルムアルデヒド の放散が高いものがあることがわかった。VOCに関しては TVOC 值でも $25 \mu \mathrm{g} / \mathrm{m}^{2} \mathrm{~h}$ 程度と非常に低い值であったが, 今回測 定した W, U, Sすべてにおいてスチレン，トルエン，ジクロロメ タン, 酢酸ブチルの放散が見られた。

7 ）接着剂からの放散は，初期に高放散のものでも 7 日目にはほほ 半減することがわかった。施工後 1 週間程度の放散期間を設ける ことで，健康影響を軽減することができると考えられる。 


\section{謝辞}

本研究の一部は，科学技術庁科学技術振興調整費（生活・社会基 盤研究 生活者ニ一ズ对応研究：室内化学物質空気污染の解明と健 康・衛生居住環境の開発，研究代表者：村上周三）により寒施した ものである。一部は壁装材料協会·当時）との共同研究である。関 係各位に深甚なる謝意を表する。また，本研究は早稲田大学理工学 総合研究センターのプロジェクトとして行われた。実験を行うに際 し，多大なご協力を戴いた島田菜穂美様（当時お茶の水女子大学大 学院), 伴野正幸様（当時早稲田大学大学院）, 田中博様（早稲田大 学大学院）に厚く御礼申し上げます。

\section{本論文に関する既発表論文}

・舟木理香, 島田菜穂美，田辺新一：小型チャンバーを用いた壁紙用接着剂か らのアルデヒド類放散速度の測定，日本建築学会大会学術講演梗概集，pp. 721-722, 1999

- R. Funaki, H. Tanaka, and S. Tanabe: Mearurements of Emission and Sink Effects for Wall Covering Materials by Using a Small Chamber ADPAC, Proc. of Indoor Air 2002, Vol. 3, pp.540-545, 2002

\section{参考文献}

1）JIS A1901：建築材料の揮発性有機化合物（VOC），ホルムアルデヒド及 U゙他のカルボニル化合物放散測定方法一小形チャンバー法, 2003

2）村上周三監修：JIS 使い方シリーズーシックハウス対策に役立つ小形 チャンバー法解説 [JIS A1901], 日本規格協会, 2003

3）田辺新一，舟木理香，島田菜穂美：小型チャンバーADPACを用いた建 材·施工材からの室内污染化学物質放散速度の測定, 日本建築学会技術報 告集第10号，pp.153-157，2000

4) S.K. Brown: Chamber Assessment of Formaldehyde and VOC Emis sions from Wood-Based Panels, Indoor Air, Vol. 9, pp.209-215, 1999

5) J.C.S. Chang, B.A. Tichenor, Z. Guo, K.A. Krebs: Substrate Effects on VOC Emissions from a Latex Paint, Indoor Air, Vol. 7, pp.241-247, 1997

6) N.L. Nagda, M.D. Koontz, P.W. Kennedy: Small-Chamber and Research-House Testing of Tile Adhesive Emissions, Indoor Air, Vol. 5, pp.189-195, 1995

7) B. Lundgren; B. Jonsson, B. Ek-Olausson: Materials Emission of Chemicals-PVC Flooring Materials, Indoor Air, Vol. 9, pp.202-208,
1999

8) J.F.Van der Wal, A.W. Hoogeveen, P. Wouda: The Influence of Temperature on the Emission of Volatile Organic Compounds from PVC.flooring, Carpet, and Paint, Indoor Air, Vol. 7, pp.215-221, 1997

9）神 卓也, 村上周三，加藤信介，伊藤一秀，近藤靖史，朱 清 宇：揮発性 有機化合物の放散・吸脱着等のモデリングとその数值予測に関する研究 (その16) Small Test Chamber を用いた各種ペイントからの化学物質放 散量測定, 日本建築学会大会学術講演梗概集, D-II, pp.192-193, 2000.9

10）市原英樹，市原真希，洞田浩文：チャンバ一実験における各種建材の温度 別放散量の研究 (その 1$) \mathrm{HCHO}$ 放散量, 日本建築学会大会学術講演梗概 集, D-II, pp.869-870, 2002.8

11）市原真希，市原英樹，洞田浩文：チャンバ一実験における各種建材の温度 別放散量の研究 (その 2) TVOC 放散量, 日本建築学会大会学術講演梗概 集, D- II, pp.869-870, 2002.8

12）池田武史，村江行忠，本橋健司，古澤友介，今井誠弘：壁装材料からの化 学物質放散挙動に関する研究（その2）小型チャンバー法 (ADPAC) に よる化学物質放散速度に関する実験，日本建築学会大会学術講演梗概集， D-II, pp.192-193，2000.9

13) ECA IAQ \& Its Impact on Man, Report No. 8: Guideline for the Characterization of Volatile Organic Compounds Emitted from Indoor Materials and Products Using Small Test Chambers, 1991

14) ASTM D5116-97: Standard Guide for Small-Scale Environmental Chamber Determinations of Organic Emissions From Indoor Materials/Products, 1997

15) Danish Standard/INF90: Directions for the Determination and Evaluation of the Emission from Building Products, 1999

16）田中 博，伴野正幸，島田菜穂美，舟木理香，熊谷一清，田辺新一：小型 チャンバーADPAC を用いたアルデヒド類, VOC 放散量の測定に関する 研究 (その 4 小型チャンバーADPACの性能試験), 日本建築学会大会 学術講演梗概集, D- II, pp.821-822, 2001

17) http://wacoa.topica.ne.jp/wacoa/index.html

18）壁装材料協会：放散試験チャンバー法一建築材料の揮発性有機化合物 （VOC）及びアルデヒド類放散速度測定一，2000

19）厚生労働省報道資料：シックハウス（室内空気污染）問題に関する検討会 中間報告書一第 1 回～第 9 回まとめ，2000～2002

20) R. Funaki, S. Tanabe: Chemical Emission Rate from Building Materials Measured by a Small Chamber, JAABE, Vol. 1, No. 2, 2002.11

21）建築材料ハンドブック，技報堂出版， 1987

(2003年 5 月 10 日原稿受理， 2003 年 6 月 5 日採用決定 